\title{
ASESMEN SEBAGAI UPAYA TINDAK LANJUT KEGIATAN IDENTIFIKASI TERHADAP ANAK BERKEBUTUHAN KHUSUS
}

\author{
Dian Puspa Dewi \\ Dosen Program Studi Pendidikan Khusus \\ FKIP Universitas PGRI Adi Buana Surabaya \\ Email: Dianpuspadewi90@gmail.com
}

\begin{abstract}
The results of the identification that have been performed on the Children with special needs become the basis for follow-up service delivery. Assessment is a follow-up of identification activities, both of which are a series of inseparable and interrelated processes. Assessment of Children with Special Needs is a systematic or regular and comprehensive process or a whole in exploring further problems to find out what problems, barriers, advantages and individual needs. In the assessment process, an assessment of the three most basic things in Children with Special Needs is the child's deficiency or disability, the surplus or potential of the child and the needs of the child. Assessments are carried out with specific implementation methods and procedures.
\end{abstract}

Keywords: Assessment, children with special needs

\section{PENDAHULUAN}

Anak berkebutuhan khusus meruapakan anak yang mengalami keterbatasan dan hambatan pada aspek perkembangan baik kognitif, fisik, sosial dan emosional sehingga memerlukan layanan khusus yang harus dipenuhi. Kebutuhan mereka berdasarkan pada keterbatasan atau hambatan yang dialaminya. Adapaun jenis layanan yang diberikan kepada mereka mencakup seluruh aspek kehidupan anak, baik layanan akademik maupun non akademik.

Terdapat beberapa kelompok anak berkebutuhan khusus antara lain: anak dengan gangguan ipenglihatan (tunanetra), anak dengan gangguan pendengaran (tunarungu), anak dengan gangguan intelegensi (tunagrahita), anak dengan gangguan fisik dan motorik (tunadaksa), anak dengan gangguan perilaku pervasif (Autisme, AD-HD). Masing-masing anak memerlukan pelayanan yang berbeda satu sama lain. Sebelum proses pemberian layanan pada anak berkebutuhan khusus, seorang praktisi pendidikan khusus harus melakukan tahapan identifikasi dan asesmen terlebih dahulu. Tahap ini bertujuan agar layanan yang diberikan kepada anak dapat tepat sasaran dan sesuai dengan karakteristik serta kebutuhan anak secara nyata.

Identifikasi merupakan proses menemukenali anak berkebutuhan khusus dari lingkungan yang heterogen untuk dicari karakteristik khusus. Pada proses ini petugas identifikasi yang berusaha mencari kekurangan yang ada pada anak. Hal ini berarti dengan membandingkan kemampuan anak "normal" dengan kemampuan anak yang diduga memiliki kebutuhan khusus. Apabila ada kesenjangan yang nyata terlihat, maka anak dapat digolongkan pada anak berkebutuhan khusus. Selain itu, proses identifikasi juga berusaha mengkalsifikasikan anak pada kelompok tertentu berdasarkan pada jenis hambatan yang dimiliki oleh anak.

Proses selanjutnya setelah anak ditemukenali, adalah asesemen. Asesmen merupakan penilaian yang sistematis dan komperehensif dalam menggali informasi lebih lanjut tentang anak terkait kekurangan, potensi dan kebutuhan yang dimiliki anak. Hasil asesmen yang telah dilakukan menjadi dasar atau acuan untuk merancang dan melaksanakan pemberian layanan pada 
anak berkebutuhan khusus. Sehingga data yang ditelusuri pada saat identifikasi ataupun asesmen merupakan data yang apa adanya dan nyata dari anak.

\section{PEMBAHASAN}

\section{Hakikat asesmen Anak} Berkebutuhan Khusus

Asesmen berasal dari bahasa inggris yaitu assesment yang berarti penilaian terhadap sesuatu. Sebagai sebuah penilaian, istilah asesmen banyak disamaartikan dengan evaluasi dan Tes. Evaluasi dan Tes didefinisikan juga sebagai sebuah proses penilaian, namun, masingmasing memiliki makna yang berbeda. Evaluasi merupakan penilaian yang dilakukan setiap akhir kegiatan pembelajaran dan bertujuan untuk mengetahui pencapaian anak pada tujuan pembelajaran yang telah ditetapkan. Asesmen merupakan sebuah proses penilaian yang dilakukan sebelum proses pembelajaran berlangsung, bahkan sebelum program pembelajaran dirancang. Sedangkan Tes ialah bagian dari evaluasi dan asesmen, yang merupakan sebuah metode dalam melakukan evaluasi dan asesmen. Tes dilaksankan kapan saja menyesuaikan kebutuhan penilaian.

Selanjutnya, kita akan fokus pada pembahasan asesmen kepada Anak Berkebutuhan Khusus. seperti yang sudah diketahui bahwa asesmen merupakan tindak lanjut dari tahap identifikasi. Asesmen Anak Berkebutuhan Khusus merupakan sebuah proses yang sistematis atau teratur dan komperehensif atau secara menyeluruh dalam menggali permasalahan lebih lanjut untuk mengetahui apa yang menjadi masalah, hambatan, keunggulan dan kebutuhan individu. Pada proses asesmen ini dilakukan penilaian terhadap tiga hal yang paling mendasar pada Anak Berkebutuhan Khusus yaitu kekurangan atau ketidakmampuan anak, kelebihan atau potensi anak dan kebutuhan yang diperlukan oleh anak.

Hasil kegiatan asesmen digunakan untuk memberikan layanan pendidikan yang dibutuhkan dengan berdasarkan modalitas (potensi) yang dimiliki individu yang diperlukan dalam menyusun program pembelajaran. Informasi yang digali dalam kegiatan asemen tidak hanya hambatan yang dimiliki anak namun juga potensi apa yang dimiliki oleh anak serta nantinya adalah kebutuhan apa yang diperlukan oleh anak.

ata yang ditelusuri dan disajikan dalam proses ini haruslah yang nyata dari keadaan anak, sehingga dapat dirancang program pembelajaran yang sesuai berdasarkan atas kekurangan, kelebihan dan kebutuhan anak. Berdasarkan hal tersebut maka guru dapat memperkirakan pembelajaran yang tepat bagi anak, apakah pembelajaran dirancang dengan sistem klasikal atau individual. Pembelajaran yang dirancang dengan sistem klasikal maka rencana pembelajaran dituangkan dalam Rencana Pelaksanaan Pembelajaran (RPP), pembelajaran dengan sistem individual rencana pembelajaran dituangkan dalam Program Pembelajaran Individual (RPP), sedangkan untuk pembelajaran keterampilan hidup pada Anak Berkebutuhan Khusus dituangkan dalam merancang Program Khusus (Progsus).

Sebagai tahapan tindak lanjut dari kegiatan identifikasi maka petugas yang melakukan kegiatan asesmenpun tidak jauh beda dengan petugas identifikasi yaitu guru, petugas sosial, orang tua 
(untuk beberapa hal) dan tenaga profesional terkait. Kegiatan asesmen ini lebih spesifik daripada kegiatan identifikasi, oleh karena itu ada beberapa bagian perlu dilakukan oleh yang memiliki kompetensi melakukan asesmen.

Petugas asesmen melakukan kegiatannya bertempat di lokasi yang mudah dijangkau oleh anak seperti di sekolah, di rumah, di unit layanan disabilitas, di balai desa, puskesmas dan sebagainya. Waktu yang digunakan untuk melakukan asesmen dikategorikan menjadi dua tahap, yaitu pertama asesmen yang dilaksanakan di sekolah oleh guru sebelum program pembelajaran dibuat. Jangka waktu yang diperlukan pada tahap ini tergantung pada program yang dibuat oleh tim, bisa 2 minggu bahkan sampai 6 bulan. Kedua, asesmen yang dilakukan selama proses pembelajaran. Asesmen ini dilakukan apabila waktu yang digunakan untuk melakukan asesmen sebelum pembelajaran tidak mencukupi, maka asesmen tetap dapat dilakukan selama proses pembelajaran berlangsung. Hasilnya dapat dijadikan dasar untuk memperbaharui rencana pembelajaran apabila hasil yang didapatkan berbeda dari hasil asesmen sebelumnya.

2. Ruang Lingkup Asesmen Anak Berkebutuhan Khusus

Asesmen merupakan salah satu tindak lanjut dari kegiatan identifikasi, khususnya pada Anak Berkebutuhan Khusus. Untuk mengetahui informasi apa saja yang ditelusuri pada kegiatan asesmen, berikut dipaparkan ruang lingkup asesmen Anak Berkebutuhan Khusus,

a. Ruang Lingkup berdasarkan aspek kehidupan anak

1) Asesmen Akademik

Asesmen kognitif merupakan asesmen pada kemampuan kognitif seseorang yang berkaitan dengan aktivitas memahami sesuatu, menguasai sesuatu, pemecahan masalah, berfikir abstrak, persepsi dan sebagainya. Kegiatan asesmen akademik yang dilakukan seorang petugas bertujuan untuk mencaritahu sejauh mana kemampuan kognitif seorang Anak Berkebutuhan Khusus yang berkaitan dengan aktivitas belajarnya dalam proses pembelajaran di kelas.

Guru sebagai petugas identifikasi dapat menyusun instrumen asesmen dengan mengacu pada Kompetensi Dasar (KD) yang tersedia pada kurikulum berdasarkan tingkatan kelas anak. KD tersebut kemudian dikembangkan menjadi indikator asesmen. Kemudian untuk mengukur indikator tersebut disediakan sejumlah pertanyaan/pernyataan yang dapat menjaring kondisi (profil) siswa yang sesungguhnya.

2) Asesmen perkembangan

Asesmen ini mengacu pada aspek perkembangan Anak Berkebutuhan Khusus yang merupakan aspek perkembangan non-akademik. Aspek perkembangan non-akademik tersebut terdiri dari aspek perkembangan

bahasa/komunikasi, sosial dan/emosional serta fisik motorik (neuromotor atau psikomotor).

Asesmen ini dilakukan oleh guru program kebutuhan khusus untuk mengurangi hambatan yang diakibatkan oleh kekhususan/kelainan utama yang dimiliki oleh anak.

3) Asesmen perilaku adaptif 


\begin{abstract}
Asesmen perilaku adaptif merupakan asesmen yang menilai sejauh mana kemampuan anak untuk melakukan aktivitasnya seharisehari. Anak Berkebutuhan Khusus memiliki hambatan utama pada intelektualnya, sehingga akan berdampak pada aspek perkembangannya yang lain. Sehingga tujuan dari asesmen ini adalah membantu anak agar dapat melakukan aktivtas sehari-harinya secara mandiri. Oleh karena itu, program pembelajaran pada Anak Berkebutuhan Khusus harus berpedoman pada ruang lingkup ini. Contohnya: makan, minum, merawat kebersihan diri, berkarya dan sebagainya.
\end{abstract}

b. Ruang Lingkup asesmen berdasarkan waktu

1) Ruang lingkup asesmen yang diberikan sebelum anak mengikuti pelajaran

a) Kemampuan menolong diri, kemampuan ini merupakan kemampuan seseorang dengan gangguan intelektual dalam mengurus dan menolong diri sendiri dengan maksud mengurangi ketergantungan kepada orang lain. Contoh: makan-minum, berpakaian dan merias diri, menjaga kebersihan (merawat) diri, keselamatan diri, orientasi lingkungan dan sebagainya.

b) Kemampuan psikomotor,merupakan kemampuan yang berhubungan dengan fisik dan motorik seseorang dengan gangguan intelektual yang meliputi gerak motorik halus dan kasar, membangun bentuk, melipat, menggunting, menggambar, menempel dan sebagainya.

c) Perkembangan sosialemosional, merupakan perkembangan atau kemampuan seseorang dengan gangguan intelektual dalam melakukan interaksi dengan orang lain dan mengelola emosionalnya. Contoh: bereaksi terhadap rangsangan dari luar, menyesuaikan diri pada situasi, bermain bersama, partisipasi dalam kegiatan, melaksanakan perintah, sikap percaya diri dan sebagainya.

d) Perkembangan bahasa, merupakan perkembangan atau kemampuan seseorang dengan gangguan intelektual dalam melakukan komunikasi dan berbahasa. Contoh: berbicara, perbendaharaan kata, menulis, menggambar dan sebagainya.

e) Perkembangan kognitif, merupakan perkembangan atau kemampuan seseorang dengan gangguan intelektual dalam aktivitas yang berkaitan dengan intelektual. Contoh: pengertian tentang ukuran, jumlah, bentuk, inisiatif, melaksanakan perintah, orientasi ruang dan sebagainya.

2) Ruang lingkup asesmen pada saat anak telah belajar di kelas Asesmen yang dilakukan kepada Anak Berkebutuhan Khusus saat anak telah menempuh pembelajaran di kelas. Asesmen ini lebih mengacu pada aktivitas 
guru dalam melakukan pembelajaran. Contohnya: penilaian untuk menentukan apa yang harus diajarkan kepada siswa secara individu dan penilaian untuk menentukan cara guru dalam mengajar siswa untuk mencapai kemajuan yang optimal.

\section{Jenis asesmen Anak Berkebutuhan} Khusus

Pelaksanaan asesmen pada Anak Berkebutuhan Khusus terdiri dari dua jenis asesmen, yang masing-masingnya memiliki perbedaan yang mendasar. Namun, jenis asesmen ini bukanlah bagian yang terpisah melainkan saling berkaitan satu sama lain dalam memperoleh informasi tentang anak. Sehingga untuk keakuratan perolehan hasil, maka kedua jenis asesmen ini dapat diterapkan pada anak. Kedua jenis asesmen Anak Berkebutuhan Khusus adalah,

\section{Asesmen formal}

Jenis asesmen ini merupakan sebuah jenis asesmen yang terstruktur dengan bimbingan atau panduan khusus untuk melakukan pengadimistrasian, pemberian nilai atau penskoran dan analisis hasil atau interpretasi dari hasil asesmen yang telah dilakukan. Contohnya: Tes Intelegensi dan Tes Pencapaian hasil belajar.

2. Asesmen informal

Asesmen informal merupakan jenis pelaksanaan asesmen yang dilakukan oleh pendidik (guru) di dalam melakukan kegiatan pembelajaran di kelas sehari-hari. Asesmen ini bertujuan untuk menngumpulkan informasi saat pembelajaran berlangsung yang nantinya menjadi dasar dalam menentukan kemampuan siswa/tingkat kinerja siswa dalam pembelajaran.
Instrumen asesmen ini dirancang oleh guru sebagai seorang pendidik, sehingga rancangan tidak terstruktur seperti pada tes standar pada asesmen formal. Sehingga tidak ada peraturan baku dalam melakukan pengadministrasian, pemberian skor dan analisis hasilnya. Namun, hasil yang diperoleh dari sesuai dengan pembelajaran yang dialami oleh anak karena asesmen informal ini berkaitan erat dengan proses pembelajaran.

Jenis dari instrumen asesmen informal ini sangat bervariasi tergantung pada aspek apa yang akan diukur. Beberapa aspek yang diukur antara lain adalah kinerja siswa secara langsung dalam pembelajaran, suasana pembelajaran baik yang melibatkan siswa secara langsung dan suasana asesmen yang melibatkan infroman lain seperti orang tua, kerabat dan guru.

\section{Metode asesmen Anak Berkebutuhan Khusus}

Sama seperti aktivitas identifikasi dilaksanakan dengan beberapa metode, asesmenpun dilaksanakan dengan beberapa metode. Berikut metode yang digunakan dalam asesmen Anak Berkebutuhan Khusus,

\section{Observasi}

Observasi memiliki arti mengamati, sehingga metode ini dilakukan dengan pengamatan terhadap anak. Pengamatan yang dilakukan terhadap cara belajar anak, tingkah laku yang muncul pada saat anak belajar, dan lain-lain. Melalui observasi dapat diketahui perilaku di dalam kelas, interaksi dengan teman sebaya, guru, orang tua. Secara umum digunakan untuk 
mengetahui keterampilan sosial anak. Instrumen yang digunakan bervariasi, tergantung pada aspek apa saja yang akan diamati dari anak.

Hasil yang diperoleh dari observasi ini biasanya berupa sifat/ karakteristik masalah perilaku di kelas. Hasil dapat dikomunikasikan secara langsung mengenai indikasi anak memiliki ganguuan intelektual dan seberapa kompleksnya permasalahan yang dialami anak. Informasi yang diperoleh ini digunakan untuk menyusun tujuan dan sasaran pembelajaran bahkan rencana pembelajaran secara umum.

2. Tes atau evaluasi hasil belajar diperoleh dengan cara memberikan tes pada setiap bidang pengajaran. Data hasil tes dapat dianalisis dengan membandingkan hasil tes masing-masing anak. Pemberian tes biasanya mengacu pada kemampuan akademik anak, namun tidak menutup guru merancang tes untuk menetahui keterampilan anak. Hasil dari tes dinyatakan dalam istilah penguasaan materi atau keterampilan tertentu atau tidak menguasai. Selain itu juga biasanya dinyatakan dalam skor untuk mengukur kemampuan seseorang secara kuantitatif.

3. Wawancara

Metode ini merupakan upaya mengumpulkan informasi yang mungkin saja susah diperoleh. Hasil dari wawancara ini berupa data deksriptif, yang kualitasnya sangat tergantung pada pengetahuan orang yang diinterview tentang keadaan anak untuk melengkapi data yang dibutuhkan. Oleh karena itu, wawancara diharapkan dilakukan kepada orang yang memiliki informasi yang lengkap seperti orang tua, keluarga, siswa dan sebagainya.

Pada umunya, kemudahan menganalisis data hasil wawancara tergantung pada kejelasan tujuan pengambilan data dan tingkat struktur instrumen yang digunakan. Keuntungan dari teknik ini jika informasi diperoleh dari orang yang benar-benar mengenali anak dan secara spontan mengatakan apa yang ia ketahui atau bahkan rasakan.

\section{Pelaksanaan asesmen Anak} Berkebutuhan Khusus

Kegiatan identifikasi dan asesmen Anak Berkebutuhan Khusus merupakan serangkaian kegiatan yang tidak terpisahkan, artinya satu sama lain memiliki kaitan dan tidak berdiri sendiri. Hasil dari identifikasi menjadi modal pada kegiatan asesmen yang dilakukan kepada Anak Berkebutuhan Khusus. Kedua kegiatan tersebut memiliki tujuan yang sama untuk menemukan dan memahami kebutuhan khusus peserta didik. Identifikasi dan tindakan lanjutnya termasuk asesmen harus dilaksanakan secara sistemati. Berikut beberapa langkah dalam pelaksanaan asesmen Anak Berkebutuhan Khusus,

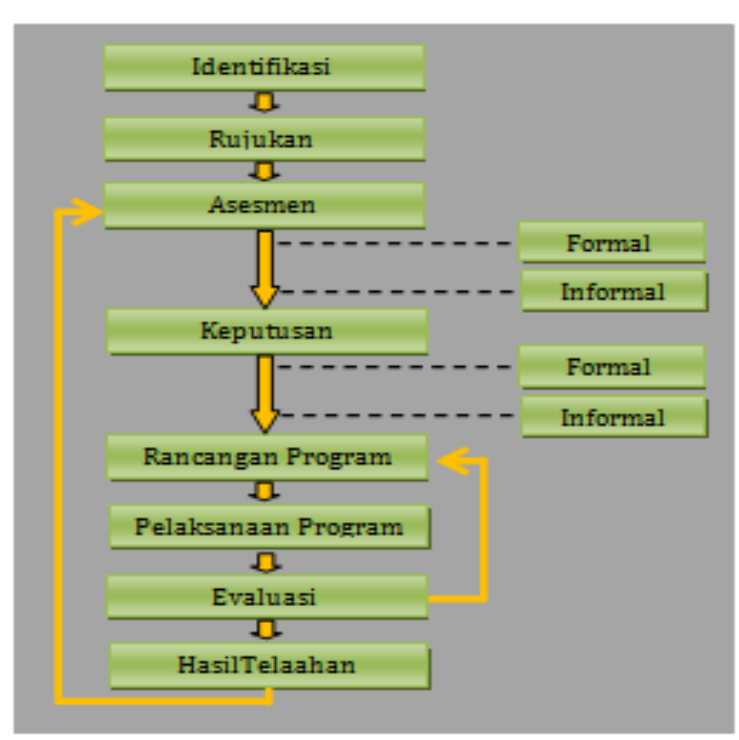

Gambar 1.Struktur kegiatan asesmen 
Anak diidentifikasi melalui beberapa metode identifikasi yang digunakan oleh petugas. Guru kelas, orang tua dan orang terdekat dengan anak dapat diikutsertakan pada proses ini. Anak yang menunjukan adanya permasalahan dirujuk kepada ahli yang relevan sesuai dengan kebutuhan.

Asesmen dilakukan kepada anak yang telah dirujuk sesuai dengan kebutuhannya. Asesmen dapat diberikan dalam bentuk tes maupun non tes dengan prosedur formal dan informal. Asesmen formal dilakukan oleh profesional dan asesmen non formal dilakukan oleh guru. hasilnya digunakan untuk menetapkan program pembelajarana anak. Selanjutnya tim ahli memutuskan tentang pelayanan yang akan diberikan kepada anak sesuai dengan hasil asesmen. Rancangan program disusun berdasarkan keputusan yang telah ditetapkan oleh tim, hal ini meliputi pertimbangan kekurangan dan kelebihan anak.

Langkah-langkah dalam melakukan asesmen sebagai berikut:

1. Peserta didik diidentifikasi melalui observasi dan wawancara. Orangtua dan orang lain yang terdekat peserta didik dapat dilibatkan dalam proses ini.

2. Peserta didik yang secara signifikan menunjukkan adanya permasalahan dirujuk kepada ahli yang relevan sesuai dengan kebutuhan.

3. Asesmen dilakukan kepada peserta didik yang telah dirujuk sesuai kebutuhan. Asesmen dapat diberikan dalam bentuk tes dan non tes dengan prosedur formal dan informal. Asesmen formal dilakukan oleh profesional dan asesmen informal oleh guru. Hasilnya digunakan untuk menetapkan Program Pembelajaran Individual (PPI).
4. Tim ahli memutuskan tentang pelayanan yang akan diberikan kepada peserta didik sesuai dengan hasil asesmen. Program pendidikan yang diindividualkan meliputi: tujuan tahunan, sasaran jangka pendek, kegiatan yang akan dilakukan untuk mencapai tujuan tersebut, serta tanggung jawab masing-masing yang terlibat.

5. Rancangan program disusun berdasarkan keputusan yang telah ditetapkan. Rancangan program ini dapat berupa program untuk meningkatkan kemampuan akademik maupun program kebutuhan khusus untuk mereduksi hambatan yang diakibatkan oleh kekhususan pada Anak Berkebutuhan Khusus.

6. Pelaksanaan program dilakukankan sesuai dengan PPI yang dihasilkan/ ditetapkan oleh tim ahli atau oleh guru. PPI yang menjadi dasar dalam penyusunan Rencana Pelaksanaan Pembelajaran (RPP) dan Program Khusus (Progsus). Sehingga memungkinkan RPP dan Progsus yang dibuat oleh guru mengisyaratkan adanya kelompok kemampuan yang berbeda dari anak dalam satu kelas.

7. Evaluasi dilakukan untuk mengetahui kemampuan belajar peserta didik. Ada garis balikan dan hasil evaluasi, untuk melihat kembali rancangan program yang disusun dan dilaksanakan. Siklus ini akan terus berjalan sehingga dicapai rancangan program yang benarbenar tepat dan sesuai dengan kebutuhan khusus peserta didik.

8. Peninjauan atas hasil yang dicapai dari program yang telah dilaksanakan penting dilakukan. Apapun hasil yang dicapai harus dikembalikan pada asesmen awal. Jika diperlukan dapat dilakukan asesmen ulang, merancang ulang program dan implementasi ulang. 


\section{KESIMPULAN}

Asesmen berasal dari istilah Bahasa Inggris Assesment yang berati penilaian. Asesmen Anak Berkebutuhan Khusus merupakan sebuah proses yang sistematis atau teratur dan komperehensif atau secara menyeluruh dalam menggali permasalahan lebih lanjut untuk mengetahui apa yang menjadi masalah, hambatan, keunggulan dan kebutuhan individu. Data yang diperoleh pada asesmen menjadi landasan petugas asesmen dalam merancang program pembelajaran kepada anak. Ruang lingkup asesmen Anak Berkebutuhan Khusus terdiri dari asesmen akademik, asesmen perkembangan dan asesmen perilaku adaptif. Kegiatan asesmen dibedakan menjadi dua yaitu asesmen formal dan informal. Asesmen dilaksanakan dengan metode observasi, tes dan wawancara.

\section{DAFTAR PUSTAKA}

Abdurrachman dan Sudjadi. (1994). Pendidikan Luar Biasa Umum. Jakarta: Depdikbud.

Berhanu, G. (2011). Inclusive Education in Sweden: Responses, Challenges, and Prospects. international journal of special education Vol 25 No 1 2011

Chiang, Linda H dan Hadadian, Azar. 2010. Raising Children With Disabilities In China: The Need For Early Interventions. International Journal Of Special Education Vol 25 No 2 2010 (Page: 113-118)

Direktorat Pendidikan Luar Biasa, Dirjen Pendidikan Dasar Dan Menengah
Depdiknas. (2004). Pedoman Penyelenggaraan Pendidikan Terpadu/ Inklusi, Alat Identifikasi Anak Berkebutuhan Khusus. Jakarta: Depdiknas

Efendi, M. (2006). Pengantar Psikopedagogik Anak Berkelainan. Jakarta: PT. Bumi Aksara

Gargiulo, Richard M. 2012. Speial Education in Contemporary Society: An Introduction to Exceptionality $4^{\text {th }}$ ed. California: Sage Publication.Inc.

Rahardja, Djaja, Sujarwanto. 2010. Pengantar Pendidikan Luar Biasa. Surabaya : Universitas Negeri Surabaya

Rejeki, D.S. \& Hermawan. 2010. Pendidikan Inklusi dan Kemampuan Menyesuaikan Diri Anak Berkebutuhan Khusus Terhadap Keberhasilan Sosialisasi. Jurnal pendidikan dan Kebudayaan, Vol. 16, Edisi Khusus II.

Santrock, John W. 2007. Perkembangan Anak: Edisi Kesebelas Jilid 1. Jakarta: Erlangga.

Somantri, Sutjihati. (2007). Psikologi Anak Luar Biasa. Bandung : Pt Refika Aditama

Sunardi dan Sunaryo. 2007. Intervensi Dini Anak Berkebutuhan Khusus. Jakarta : Depdiknas

Wardani, I.G.A.K. 2007. Pengantar Pendidikan Luar Biasa. Jakarta: Universitas 